DOI: https://doi.org/10.30749/2177-8337.v23n45p25-60

\title{
MICROEXPRESSÕES FACIAIS: LENDA OU REALIDADE?
}

\section{FACIAL MICROEXPRESSIONS: LEGEND OR REALITY?}

\author{
Antonio Baptista Gonçalves* \\ Fabiani Mrosinski Peppi**
}

\begin{abstract}
Resumo: O ser humano tem a capacidade de mascarar e ocultar emoções. O faz com interesses diversos como proteger seus sentimentos mais íntimos, ocultar comportamentos e, até, evitar associações a crimes. Essa capacidade dificulta as atividades policiais e processuais a fim de se verificar ou descartar um suspeito ou a associar seu comportamento com as provas colacionas no processo penal. Os meios de prova são essenciais inclusive para se evitar que um inocente possa ser erroneamente condenado. Nesse sentido, o estudo comportamental das expressões faciais é capaz de excluir as mentiras e/ou inverdades ao longo de um interrogatório, depoimento ou demais atos realizado ao longo de uma investigação. Resta regulamentar sua atividade no Código de Processo Penal Brasileiro.
\end{abstract}

Palavras-chave: Emoção. Expressão Facial. Criminologia. Paul Ekman.

Abstract: The human being has the ability to mask and hide emotions. It does so with diverse interests such as protecting their innermost feelings, hiding behavior, and even avoiding associations with crime. This capacity hinders police and procedural activities in order to verify or dismiss a suspect or to associate his or her behavior with the evidence involved in the criminal process. The means of proof are essential even to prevent an innocent from being wrongly condemned. In this sense, the behavioral study of facial expressions is able to exclude lies and / or untruths throughout an interrogation, testimony or other acts carried out during an investigation. It remains to regulate its activity in the Brazilian Criminal Procedure Code.

KeyWords: Emotion. Facial expression. Criminology. Paul Ekman.

\footnotetext{
* Advogado, Presidente da Comissão de Criminologia e Vitimologia da OAB/SP, Pós-Doutor em Ciência da Religião pela PUC/SP, Pós-Doutor em Ciências Jurídicas pela Universidade de La Matanza. Doutor e Mestre em Filosofia do Direito pela PUC/SP, Especialista em Direitos Fundamentais pela Universidade de Coimbra, Especialista em International Criminal Law: Terrorism's New Wars and ICL's Responses pelo Istituto Superiore Internazionale di Scienze Criminali, Especialista em Direito Penal Econômico Europeu pela Universidade de Coimbra, Pós-Graduado em Direito Penal Econômico pela Fundação Getúlio Vargas - FGV, Bacharel em Direito pela Universidade Presbiteriana Mackenzie e Bacharel em Filosofia pela PUC/SP.

** Advogada, Mestranda em Ciências Criminológico-Forenses pela Universidad de Ciencias Empresariales y Sociales, Pós Graduada em Direito Penal e Processual Penal pela Faculdade Damásio, Bacharel em Direito pelas Faculdades Metropolitanas Unidas - FMU e Membro da Comissão de Criminologia e Vitimologia da OAB/SP.
} 


\section{INTRODUÇÃO}

Se engana aquele que considera a linguagem ${ }^{1}$ como uma atividade restrita à oralidade. A comunicação é feita por muitos outros elementos não adstritos ao ato de falar sonoramente, isto é, falando e conversando. É possível se comunicar através de sinais, gestos e, mais do que isso: igualmente se comunicar através das expressões faciais ${ }^{2}$, a forma de andar, a postura. Em verdade, a comunicação verbal perfaz apenas 7\% $\%^{3}$ da comunicação humana ${ }^{4}$ (EKMAN, 1999; MATSCHNIG, 2015; WHALEN et al., 2013).

Por séculos a comunicação humana se manteve por meio de um código de expressões faciais e corporais variadas, pelas quais o homem primitivo demostrava suas emoções e sentimentos, criando assim, uma forma primitiva e simples de linguagem.

Ademais, a comunicação se faz de maneira consciente e inconsciente, pois, como veremos, a linguagem corporal, as microexpressões se manifestam de maneira

\footnotetext{
${ }^{1}$ Derivado de língua, quer exprimir o vocábulo o modo de serem enunciados os pensamentos, seja por viva voz ou por escrito, ou mesmo por sinais. A linguagem, pois, mostra-se a língua em ação, falada ou escrita, para comunicar os pensamentos de pessoa a pessoa. Pode ser também mímica, isto é, revelada por sinais.

Juridicamente, é por ela, em regra, que ocorre a manifestação da vontade, para que os atos jurídicos se promovam e as convenções ou os contratos se formalizem, validamente. Mas, por princípio instituído em Direito, para evidência da vontade manifestada por meio da linguagem, por vezes se faz mister a interpretação literal da mesma, isto é, a verificação do sentido das palavras, em que foi expressa. Em tal caso, pois, manda a regra que mais se atenda à intenção do agente, que ao sentido literal da linguagem. No entanto, semelhante interpretação somente procederá quando a linguagem anotada é confusa ou insuficiente. Se é certa e clara, a intenção nela se contém certa e claramente. O sentido da expressão será, pois, a declaração da própria vontade, desde que não há melhor maneira de manifestá-la, inequivocamente. De modo que, quando a linguagem não traduz com perfeição a vontade, é que se faz mister a pesquisa da intenção, de outras maneiras verificada, para que se faça a legítima interpretação da vontade manifestada. (SILVA, 2012, p. 850).

2 Expressões faciais ocorrem quando os músculos da face funcionam em concerto, isto é, produzem uma comunicação não verbal. Primordialmente, acreditava-se que se tratava de um comportamento aprendido, no entanto, estudos psicológicos em tribos como Papua em Nova Guine mostraram que as expressões faciais podem predizer emoções universais (EKMAN, 1999).

3 "Você imaginaria que, quando encontramos uma pessoa pela primeira vez, $93 \%$ do que comunicamos é por nossa linguagem corporal? $55 \%$ da nossa atenção direciona-se à postura, ao gestual e à expressão facial do interlocutor, e outros $38 \%$ ao volume ou à melodia da voz. Sendo assim, o conteúdo do que ouvimos, em oposição à maneira como nos é transmitido, nos interessa $7 \%$. Nenhuma surpresa, pois a linguagem corporal do interlocutor nos revela mais sobre a sua personalidade do que mil palavras" (MATSCHNIG, 2015, p. 13).

${ }^{4}$ É sabido que dentre os diferentes sinais não-verbais de expressão da emoção, as expressões faciais são aquelas com maior destaque, mediando boa parte das interações sociais e da comunicação nãoverbal. Através da observação da expressão alheia, pode-se inferir informações sobre o estado emocional de uma pessoa, suas intenções e, inclusive, suas reações aos eventos apresentados em nosso ambiente (WHALEN et al, 2013).
} 
inconsciente no ser humano e, com elas, é possível se deduzir ou interpretar esses sinais a fim de verificar a possibilidade de uma mentira ou de um ocultamento de emoções.

A involuntariedade de certas expressões denota comportamentos, afinal, o ato de salivar é comum ante a um prato com cheiro agradável. Da mesma forma quando se enfrenta uma situação de medo e seus batimentos cardíacos saem do ritmo convencional em decorrência do aumento da emoção.

De tal sorte que seu estudo pode propiciar importante contribuição no campo forense. $E$, alguns entusiastas, defendem inclusive sua utilização alternativamente ao polígrafo.

A temática das expressões faciais não é um assunto novo fora do Brasil, contudo em terras tupiniquins seus estudos e conhecimentos ainda são bem incipientes. O tema teve contribuição inestimável de Charles Darwin como uma extensão de suas pesquisas que culminaram na sua mais reconhecida obra A origem das Espécies. A questão das expressões faciais em seres humanos ocuparam Darwin e derivaram em mais duas obras que resultaram em grandes e pesadas críticas o que relegaram a importância do tema a uma relativização.

E, com base em seus estudos Paul Ekman deu uma nova guinada sobre o tema com importante descoberta que, podemos dizer assim, revolucionou e pautou os estudos subsequentes sobre o tema.

O assunto é complexo e será melhor descompactado adiante, todavia, a televisão teve papel preponderante no acesso a questão das expressões faciais. Afinal, o grande público teve a possibilidade de contato com o tema através de uma obra ficcional feita para a televisão no começo do século, falamos da série que foi veiculado pelo canal Fox Lie to me, que estreou nos Estados Unidos da América em 2009.

Essa série se propôs a apresentar o que vem a ser a microexpressão com base nos estudos de Paul Ekman ${ }^{5}$ e veio a reboque de um movimento de exploração do cenário forense com farto investimento nesse veio com uma gama de séries

\footnotetext{
${ }^{5}$ Recebeu seu PHD em Psicologia Clínica. Eleito um dos 100 psicólogos mais importantes do século XX pela American Psychological Association (APA) e considerado o maior psicólogo estudioso do comportamento facial; considerado pela NY Times como uma das 100 figuras mais influentes no mundo e com vários prêmios de distinção científica (CUVE, 2015, não paginado).
} 
como: Criminal Minds, The Mentalist, Bones, The 4400, Fringe e a própria Lie To Me. A duração dessas séries variou e se deveu a continuidade por conta do seu apelo para com o público, tanto que a primeira ainda perdura. E, o uso da perícia e seus meandros foi um veio muito explorado através da série CSI, abreviação para Crime Scene Investigation, que fez um sucesso arrebatador nos Estados Unidos a ponto de lançar derivados e subséries sobre o mesmo tema, dado aos altos índices de audiência que mantiveram a série no ar por mais de uma década, como CSI: NY; CSI: Las Vegas; CSI Cyber, além de NCIS e suas derivadas. Mas voltemos à série Lie to me.

Em janeiro de 2009, a Fox, uma das maiores redes de televisão dos Estados Unidos, estreou em sua programação a série Lie To Me. Seu episódio piloto foi assistido por, aproximadamente, 13 milhões de telespectadores, de acordo com o Nielsen, instituição que mede a audiência nos EUA. A série teve curta duração restrita a três temporadas, mas seus ganhos ficaram e, principalmente, partes da obra de Paul Ekman foram conhecidos.

Assim, o primeiro passo é compreender o que vem a ser a questão das expressões faciais, para, em um segundo momento analisar se, de fato, pode-se usar no direito ou apenas e tão somente deverá ficar adstrita ao mundo da ficção e das séries de televisão.

\section{ESTUDO DAS EXPRESSÕES FACIAIS: DE DARWIN A EKMAN}

O primeiro a expor qualquer visão sobre a expressão das emoções foi o anatomista Charles Bell ao afirmar que determinados músculos do homem existiam apenas para a expressão das emoções. Porém, a temática das expressões faciais e seu estudo teve sua abordagem inicial com Charles Darwin em uma obra que ganhou menos destaque do que a Origem das espécies, mas que foi preponderante por se tratar do estudo do ser humano, tendo em vista que seu livro mais conhecido não abordou a evolução dos seres humanos.

O estudo do homem foi a evolução, sem nenhum trocadilho, das pesquisas de Darwin, pois, enquanto a Origem das espécies data de 1859, seus livros 
posteriores: a Origem do homem e a seleção sexual é de 1871 e a Expressão das emoções no homem e nos animais do ano seguinte ${ }^{6}$ (FEITOSA, 1999).

A expressão das emoções no homem e nos animais é composta por 13 capítulos. Ao longo destes, Darwin abordou os princípios gerais da expressão, os meios de expressão nos animais, as expressões especiais de animais, e, também, as expressões especiais do homem: sofrimento e choro; desânimo, ansiedade, tristeza, abatimento e desespero; alegria, bom humor, amor, sentimentos de ternura e devoção; reflexão, meditação, mau humor, amuo e determinação; ódio e raiva; desdém, desprezo, nojo, culpa, orgulho, desamparo, paciência, afirmação e negação; surpresa, espanto, medo e horror; preocupação seja consigo ou para com os demais, vergonha, timidez e modéstia.

Alfred Russel Wallace, contemporâneo de Darwin, aponta o relevante uso de gravuras para ilustrar os argumentos do autor:

O livro está ilustrado admiravelmente, tanto por xilogravuras como por uma série de fotografias que representam as expressões mais características. Está escrito com toda clareza e precisão habituais do autor, e embora algumas partes sejam um pouco maçantes, considerando a quantidade de detalhes diminutos, há no todo um tanto de observação aguda e anedota engraçada, talvez para torná-lo mais atraente para os leitores em geral, mais do que qualquer um dos trabalhos anteriores do Sr. Darwin (WALLACE, 1873, p. 118).

Sobre as conclusões de Darwin, a partir da afirmação de Wallace, se manifesta Maria Ângela Guimarães Feitosa:

No texto principal de The Expression of the Emotions, Darwin expõe seus três princípios gerais "explicativos das expressões e gestos usados involuntariamente pelo homem e pelos animais inferiores, sob a influência de várias emoções e sensações". São eles o princípio dos hábitos associados de serventia "ações complexas de serventia direta ou indireta em certos estados da mente, a fim de aliviar ou gratificar

\footnotetext{
${ }^{6}$ A primeira edição de The Expression of the Emotions in Man and Animals foi publicada na Grã Bretanha em 1872, um ano depois da publicação de Descent of Man e treze anos depois de The Origin of Species. A despeito do interesse de Darwin em efetuar modificações ao texto, uma segunda edição só foi publicada em 1889, sete anos após sua morte, sob a supervisão de Francis Darwin, filho de Charles, o qual incluiu algumas das modificações indicadas por Charles. Reimpressões subsequentes, inclusive a edição de 1965 da Universidade de Chicago, que serviu de base à recente tradução da obra para o português pela Companhia das Letras, originaram-se da primeira edição inglesa. A organização de uma terceira edição em língua inglesa foi confiada a Paul Ekman, autoridade nas áreas de comunicação não verbal e de expressão facial das emoções em particular, cujo trabalho meticuloso acrescentou valor especial a este clássico por si só importante para o estudioso do comportamento. (FEITOSA, 1999, p. 265).
} 
certas sensações, desejos, etc. O princípio da antítese, de acordo com o qual "certos estados da mente levam a certas ações habituais, que são de serventia, mas quando um estado mental diretamente oposto é induzido, há uma forte tendência involuntária do desempenho de movimentos de natureza diretamente oposta"; e o princípio de ação direta do sistema nervoso, de acordo com o qual ações expressivas de certos estados mentais são o resultado direto da constituição do sistema nervoso, e são independentes de desejo e em grande parte de hábito (FEITOSA, 1999, p.33-34).

Darwin, com o objetivo de estudar os gestos e, também, as expressões da raça humana, produziu um questionário em forma de folheto que foi intitulado de "Queries about expression" ("Questões sobre a expressão"). Nele elaborou um conjunto de perguntas e as destinou para várias pessoas ao longo do mundo, mas com uma peculiaridade comum: estar em contato com povos primitivos em diferentes regiões do globo. O resultado foi um conjunto de 36 respostas, um feito a se considerar dadas as condições da época de envio e recebimento, além dos problemas que envolviam o contato humano com os próprios povos primitivos.

Na própria obra de Darwin há a reprodução das perguntas:

1. Exprime-se a surpresa pelo arregalar dos olhos e da boca e pela elevação das sobrancelhas? 2. A vergonha produz enrubescimento, quando a cor da pele nos permite percebê-lo? Se sim, até onde desce pelo corpo? 3. Quando um homem está indignado ou desafiador, ele franze o cenho, mantém cabeça e corpo erguidos, apruma os ombros e cerra os punhos? 4. Quando se concentra ou tenta resolver algum problema, ele franze o cenho ou enruga a pele abaixo das pálpebras inferiores? 5. Quando abatido, desce os cantos da boca e eleva a extremidade interna das sobrancelhas pela ação desse músculo que os franceses apelidaram de "músculos de sofrimento"? Nesse estado, as sobrancelhas fazem-se levemente oblíquas, com um pequeno inchaço em sua extremidade medial; e o meio da testa fica enrugado, não toda a sua extensão, como quando se elevam as sobrancelhas exprimindo surpresa? 6. Quando satisfeito, brilham seus olhos, enruga-se a pele em volta destes e retraem-se os cantos da boca? 7. Quando um homem olha para outro com desprezo ou ironia, ergue-se o canto do lábio superior por sobre o canino do lado pelo qual ele o está encarando? 8. Pode uma expressão de obstinação e tenacidade ser reconhecida principalmente pela boca firmemente fechada, pelo cenho baixo e pelas sobrancelhas levemente franzidas? 9. O desdém é exprimido por 
uma leve protrusão dos lábios e discreta expiração com o nariz empinado? 10. Manifesta-se o nojo virando-se o lábio inferior para baixo e elevando-se levemente o lábio superior com uma súbita expiração, como um vomitar incipiente ou cuspir? 11. O medo extremo é expresso aproximadamente da mesma maneira que o fazem os europeus? 12. O riso pode chegar ao extremo de fazer com que lacrimejem os olhos? 13. Quando um homem quer demonstrar que não pode impedir algo ou que ele mesmo não consegue fazer alguma coisa, ele encolhe os ombros, vira para dentro os cotovelos e estende as mãos para fora com as palmas abertas; e as sobrancelhas são erguidas? 14. As crianças, quando emburradas, fazem bico ou protraem fortemente os lábios? 15. Expressões de culpa, malícia ou ciúme podem ser reconhecidas, ainda que eu não consiga defini-las? 16. Balança-se a cabeça verticalmente na afirmação e horizontalmente na negação? (DARWIN, 1872).

Darwin concluiu que devido à grande semelhança existente entre as expressões faciais e os gritos inarticulados emitidos pelo homem e pelos animais quando expostos às mesmas condições, essas características teriam sido adquiridas, provavelmente, como herança de alguma forma silvestre de parentesco próximo, o que se harmonizava com sua tese da descendência de um ancestral comum (DARWIN, 1872).

Na mesma obra Darwin afirmou que as emoções faciais de seres humanos e animais possuíam o objetivo comum de se comunicar, sendo um elemento fundamental e reciprocidade entre as espécies. Por exemplo, se você mostrar um sorriso falso para um cachorro, ele irá reagir com agressividade e não com um abano de cauda amistoso, da mesma forma se você mostrar um sorriso verdadeiro para outro ser humano, é bem provável que você receberá de volta um sorriso como resposta (ROBERTO; LUIGI, 2017, p. 16).

De acordo com Russel e Fernández-Dols (1997), a obra não foi tão bem recebida quanto A Origem das Espécies ${ }^{7}$ e, após a morte do autor, ficou relegada ao esquecimento, ainda que com alguns debates sobre as teorias do autor e suas questões relacionadas às expressões faciais ${ }^{8}$, até sua atualização por Paul Ekman ${ }^{9}$. E

\footnotetext{
7 Toda a gente sabe que Darwin escreveu acerca de expressões faciais, mas nem toda a gente concorda com aquilo que ele queria dizer (RUSSELL; FERNÁNDEZ-DOLS, 1997).

${ }^{8}$ A partir da interpretação dos trabalhos de Darwin, iniciam-se questões controversas no estudo das expressões faciais, que se mantêm durante décadas de pesquisa, tais como: "Existe ou não uma
} 
sua importância veio à tona quando da atualização e da retomada das pesquisas baseadas nos estudos de Charles Darwin ${ }^{10}$. Foi Ekman ${ }^{11}$, em 1967, que introduziu o paradigma que modificou a visão sobre o tema das expressões faciais, nas palavras de Silvio José Lemos Vasconcellos:

Ekman, juntamente com seu colega de pesquisa Wally Frisen, examinou centenas de horas de vídeos dos nativos da região, gravados por outros estudiosos antes de sua chegada à ilha. Nenhuma expressão facial que pudesse caracterizar-se como incongruente com as seis emoções básicas já identificadas em outras culturas (alegria, tristeza, raiva, repugnância, medo e surpresa) surgiu nessa etapa do estudo. Para romper, então, com as limitações linguísticas que eram comumente alvo de críticas em trabalhos anteriores, Ekman elaborou e traduziu uma série de histórias para o idioma nativo. Tais histórias retratavam a realidade social e cultural dos nativos da ilha e eram protagonizadas por personagens que, considerando os fatos narrados, encontrar-se-iam, ao término da história, em um estado emocional específico. A partir disso, os participantes das pesquisas deveriam, depois de escutarem essas mesmas histórias, identificar a emoção correspondente em fotos

ligação directa entre expressões faciais e emoções?"; "Existe ou não uma universalidade das expressões faciais da emoção?"; "Que tipo de informação as expressões faciais transmitem?"; "Existem ou não expressões faciais emocionais inatas e prototípicas ligadas a emoções básicas?" "As expressões das emoções são involuntárias ou deliberadas?" (SOUSA, 2010, p. 17-4).

${ }^{9} \mathrm{O}$ livro está organizado em três seções principais. A primeira delas contém um prefácio à terceira edição, onde Ekman tece uma série de considerações técnicas sobre a organização desta edição; a reprodução do curto prefácio à segunda edição, escrito por Francis Darwin; e uma Introdução à Terceira Edição, em que Ekman usa parte substancial do espaço argumentando porque, tendo The Expression of the Emotions sido um sucesso de venda logo após o lançamento, caiu no esquecimento por 90 anos e só nas últimas três décadas foi redescoberto. Ele identifica cinco críticas centrais ao trabalho de Darwin: de recurso ao antropomorfismo; de uso de evidência anedótica; de adoção do princípio lamarckiano de hereditariedade de características adquiridas; de negligência para com o valor comunicativo na origem das expressões emocionais; e, o que Ekman considera especialmente devastador, de confronto aos dogmas vigentes, ao propor que as expressões são inatas e de que estes sinais de nossas emoções são produto de nossa evolução. Ao avaliar essas críticas ele parcialmente as endossa, parcialmente contra argumenta em função de características do método de Darwin que permitiriam minimizar seu impacto, e parcialmente as reinterpreta, à luz do Zeitgeist político. Na avaliação de Ekman a renovação no interesse pelo livro de Darwin precisou esperar a ação conjunta de alguns fatores que levaram a um entendimento mais abrangente sobre a determinação do comportamento humano: a forte evidência produzida nas décadas de 60 e 70 acerca da universalidade das expressões, o desencanto com as limitações do behaviorismo e a emergência da legitimidade de se estudar pensamentos e ideias, com a ciência cognitiva. Ainda segundo Ekman, foram influentes o crescimento rápido da genética do comportamento, o surto de conhecimento sobre o cérebro, o Projeto Genoma Humano, e o desvelar contínuo de como muitas diferenças individuais têm base genética (FEITOSA, 1999, p. 266).

10 No entanto, a corroboração dos pressupostos de Darwin quanto à universalidade das emoções básicas só veio a ocorrer depois de, aproximadamente, um século da publicação dos trabalhos desse naturalista. Para tanto, um refinamento metodológico nas pesquisas que vinham sendo feitas sobre o tema mostrou-se necessário (VASCONCELLOS et al. 2014, p. 126).

${ }^{11}$ Nós necessitamos de aprender que tipo de informação deriva de uma expressão facial, de quem e em que contextos sociais e culturais. (EKMAN, 1989, p. 143-164). 
contendo expressões faciais representativas das seis emoções básicas, sem a necessidade de nomeá-las. Além disso, a possibilidade de que os participantes estivessem familiarizados com a expressão facial a partir de outras fontes de informação disponíveis nas culturas letradas foi totalmente minimizada no trabalho com os habitantes de Papua Nova Guiné, pois eles nunca haviam tido contato com habitantes de outras culturas (VASCONCELLOS et al. 2014, p. 126).

\section{Lucas Martins Amaral destaca a relevância do estudo e quais foram os} resultados do mesmo:

Esses estudos foram mostrados a alunos de uma universidade americana, que foram capazes de interpretar quais emoções os nativos Fore quiseram expressar. Caso fosse algo cultural, como até então era defendido, os universitários não seriam capazes de interpretar corretamente. Cabe ressaltar que o principal erro de interpretação, tanto dos nativos quanto dos universitários, foi a confusão entre surpresa e medo. Seus estudos apresentados em 1969, na conferência anual de antropologia, forneceram a evidência mais forte até agora de que Charles Darwin estava correto ao afirmar que expressões faciais são universais. Apesar de não terem tido nenhum contato com seres humanos de outras culturas, os Fores apresentaram os mesmos padrões de emoção encontrados em outras partes do mundo (EKMAN, 2011 apud AMARAL, 2017, p. 28).

\section{A importância do estudo de Ekman ${ }^{12}$ se deveu ao fato da identificação de} emoções básicas e universais ${ }^{13}$ que se repetem e independem do relativismo cultural $^{14}$. Após esses estudos da Nova Guiné se passou a considerar a intensidade

12 Ekman e Friesen (1969) prosseguiram estes estudos transculturais, investigando diferentes sinais não verbais de comunicação (expressões faciais, gestos e postura corporal) em busca de informações acerca de significados, funções, origens, categorizações, atribuindo às expressões faciais a função de transmitir emoções de forma universal (COSTA-VIEIRA; SOUZA, 2014, p. 89-156).

${ }^{13}$ A Abordagem da Expressão Emocional (Ekman, 1989; Ekman; Friesen; Ellsworth, 1982) afirmou também que os aspectos "universais" poderiam ser procurados nas expressões típicas das emoções básicas, ao passo que as diferenças culturais deveriam ser procuradas nos estímulos ambientais que desencadeiam reacções emocionais específicas, nas regras que governam e orientam a expressão nas diferentes situações (regras de exibição) e em algumas consequências da activação emocional. Pela realização de estudos inter-culturais, estes autores afirmam que há expressões faciais específicas que estão universalmente associadas a determinadas emoções. Na sequência desta ideia foi formulada uma teoria da expressão facial das emoções, denominada Teoria Neurocultural, com o objectivo de enfatizar dois factores - um relativo aos aspectos universais e outro às diferenças culturais. (SOUSA, 2010, p. 17-41).

${ }^{14}$ É nesse ponto que Paul Ekman surge como a figura que articula os dois posicionamentos até então predominantes no estudo das expressões: a perspectiva evolucionista e a cultural/relativista. Como aponta Ekman (1970), que tinha como objetivo reconciliar essas duas perspectivas, existem "estímulos evocadores" das expressões faciais e que, em sua maioria, são aprendidos. Assim, por mais que exista o caráter evolucionista, o que aponta que as expressões faciais são universais (Ekman, 1993; 1996; Ekman; Matsumoto; Friesen, 1997), o componente cultural (ambiental) é de suma importância como evocador de emoções/expressões. (SILVA, 2018, 74-87). 
das expressões faciais o que abriu uma gama de possibilidades visto que a face humana é formada por 44 músculos que podem produzir mais de 10.000 expressões (FREITAS-MAGALHÃES, 2011), com uma análise que pode depender ou não do contexto para identificar a expressão facial ${ }^{15}$, como veremos mais adiante.

Para Bucks e Radford (2004 apud COSTA-VIEIRA; SOUZA, 2014, p. 89-156):

Compreender a emoção do outro está associado a questões de relevância e competência social, como interação e empatia, e sofre influência de diferentes fatores, como regras culturais (Ekman, 2003), intimidade com o outro (Ma-Kellams \& Blascovitch, 2012), contexto ambiental e emocional (Marian \& Shimamura, 2012) e até posturas corporais (Dael, Mortillaro, \& Scherer, 2012). Déficits no processamento emocional são identificados como um mecanismo central para dificuldades comportamentais e de interação social, já que os indivíduos acometidos de tais déficits tendem a interpretar equivocadamente as "deixas emocionais" que normalmente ajudam a guiar seus comportamentos, incluindo dificuldades no reconhecimento de expressões faciais e prosódia.

O rosto, ou melhor, a face, é a parte mais visível e notada no contato social e, por assim o ser é um importante canal de comunicação ${ }^{16}$, ainda que em determinadas culturas, como a muçulmana, as mulheres cobrem seus rostos inteiramente, algumas deixam os olhos visíveis e outras nem. Nesses casos não há como se analisar qualquer expressão facial, contudo, o corpo também produz gestos e, por eles também é possível se comunicar.

\footnotetext{
${ }^{15} \mathrm{Na}$ formulação original da abordagem emocional (Ekman, 1989) a expressão facial é independente e não necessita do contexto para ser interpretada em termos de significado. Contudo, Ekman (1997) afirma mais tarde que, quando uma expressão é vista fora do contexto, sem discurso, movimento do corpo, postura e conhecimento do que está acontecer, esta transmite informação, mas não tanta como quando é vista no contexto. Fernández-Dols e Carroll (1997) afirmam que todos os autores que desenvolveram o Programa de Expressão Facial enfatizaram a importância da expressão facial como fonte independente e auto-suficiente de informação emocional. Situando-se numa linha de investigação alternativa, estes autores realçam a ideia de que, tal como qualquer estímulo, a interpretação das expressões faciais depende do contexto. Se para a abordagem emocional, o que é importante é a quantidade de informação, para estes autores é o tipo de informação que é completamente alterado, diferente, e por isso a expressão facial não pode ser dissociada do contexto. (SOUSA, 2010, p. 17-41).

$1^{\mathbf{1 6}} \mathrm{O}$ primeiro é um sistema para medição da atividade muscular das diversas expressões faciais, que permite identificar 44 unidades de ação, de Aus e FACS, em 2002, do rosto que se operam em duas áreas: superior (testa, os sobrolhos e os olhos) e a inferior, (faces, nariz, boca e queixo), enquanto o segundo é uma ferramenta para entender como as ações musculares das expressões podem configurar conceitos psicológicos. A distinção é feita através das análises anatômica, óssea e muscular. (FREITAS-MAGALHÃES, 2013).
} 
No entanto, se as emoções transmitem sinais, voluntários ou não, existem pessoas que aprendem a mascara-las, ou nascem com problemas e/distúrbios que o tornam incapazes de sentir qualquer emoções, como por exemplo os psicopatas. Assim, a análise das expressões faciais se torna um problema para aqueles que não transmitem os sinais característicos comuns das pessoas. Passemos a nos ocupar das questões relacionadas às expressões faciais.

\section{EXPRESSÕES FACIAIS E OS CRIMES}

As expressões faciais e mais do que elas, as emoções são inerentes aos seres humanos e com elas as reações são mais bem notadas na face das pessoas: uma alegria, tristeza, raiva, repugnância, medo, surpresa, desejo, euforia, angústia, interesse, são algumas das reações que podem ser notadas nas pessoas.

Por mais preconceituoso que seu subconsciente possa ser, ele dificilmente elege apenas um único gesto. Ao contrário, alimenta-se de uma série complexa de mensagens, conhecida como conjuntos de sinais. Da próxima vez que se encontrar com algum desconhecido, tente lembrar o que você pensou sobre essa pessoa quando a viu pela primeira vez. Se achar mais fácil poderá fazer essa experiência usando uma foto de revista. A parte lógica do seu cérebro provavelmente lhe dirá que você estava com a mente totalmente livre de preconceitos. Se tivesse que fazer uma lista, ela provavelmente incluiria o contato visual e o olhar, a expressão facial, os gestos e a postura, o tom da voz, o comportamento espacial, o contato físico a aparência e o modo de se vestir. Tudo isso compõe a nossa linguagem corporal individual (JAMES, 2008, p. 11).

Esses sentimentos estão presentes em uma conquista, em alcançar uma meta, em uma viagem, mas também no cometimento de delitos, como um assalto, um latrocínio, um assassinato. Todavia, existem determinadas pessoas que são incapazes de exprimir suas emoções e, portanto, a capacidade de leitura, ou melhor, identificação de reações se reduz sensivelmente, falamos dos psicopatas.

A psicopatia é um transtorno de personalidade grave em que os indivíduos apresentam uma capacidade alterada de inibir comportamentos socialmente reprováveis, bem como deficiências referentes à compreensão e experiência de determinadas emoções. Indivíduos acometidos pelo transtorno tendem a se mostrar menos afetados pelas emoções alheias, sendo, dessa forma, mais propensos 
a agir contra as pessoas com as quais estabelecem interações sociais (VASCONCELLOS, 2014, p. 125).

Nas escolas penais e nos conceitos de criminologia existia inclusive uma classificação criada por Cesare Lombroso sobre os tipos de criminosos e a possibilidade de identificação de características físicas dessas pessoas a fim de evitar que os mesmos possam voltar ao convívio social e, por conseguinte, praticarem novos delitos. Essa classificação foi modificada nas últimas décadas na psicologia e, o moderno entendimento, associa, inclusive a disfunções na amídala.

O ponto de partida para a moderna concepção da psicopatia está nos trabalhos desenvolvidos por Hervey Cleckley (1941), que deu ênfase aos déficits afetivos como sendo o componente nuclear do transtorno. Nos últimos 50 anos, os estudos da psicopatia têm se pautado na proposta de Cleckley, de que indivíduos com esse transtorno apresentam disfunções no processamento emocional e, com o desenvolvimento de recursos de neuroimagem, em alterações neuroanatômicas. A amígdala é uma das estruturas mais primitivas da espécie humana e, dentre outras funções, está diretamente ligada ao processamento emocional, principalmente aquele de emoções de medo e tristeza. A visão predominante atual é a de que a psicopatia e os déficits cognitivos e emocionais que caracterizam o transtorno, e o distingue dos demais, refletem uma disfunção específica da amígdala. (VASCONCELLOS, 2014, p. 125-126)

O psicopata se caracteriza por sua falta de empatia ${ }^{17}$, isto é, incapacidade de sentir ${ }^{18}$, sobre os transtornos de personalidade, Hilda Morana (2006, p. 74-79):

17 As pesquisas contemporâneas têm apontado nas experiências infantis a presença de fatores de risco elevado para o desenvolvimento de quadros psicopatológicos. Uma revisão sobre o desenvolvimento de transtornos de personalidade (Johnson et al., 2005) relacionou diversos estudos confirmando que crianças e jovens submetidos a experiências traumáticas (tais como abuso físico/psicológico, negligência, doença mental parental, punição excessiva e agressiva) seriam, potencialmente, mais vulneráveis à presença de traços ou sintomas de transtornos de personalidade. Estes, depois de cristalizados, associam-se fortemente à violência, abuso de drogas, tentativas de suicídio, comportamentos destrutivos e criminosos, institucionalização, prejuízo global no rendimento e desorganização familiar. (...) Quando se mostram inflexíveis e desadaptativos para a cultura do sujeito, causando mal-estar subjetivo ou prejuízo funcional importante, podem caracterizar-se como um transtorno. Um transtorno de personalidade (TP), independente de sua tipologia específica, manifesta-se, então, em pelos menos duas áreas da vida, envolvendo a cognição, a afetividade, o funcionamento interpessoal ou controle dos impulsos, não sendo apenas resposta a estressores específicos. Ainda assim, o contato com a realidade mantém-se preservado e, quase sempre, esses traços não são percebidos pelo sujeito como estranhos ou indesejáveis, o qual avalia positivamente (portanto, de modo equivocado) o impacto dos mesmos sobre o ambiente (DAVOGLIO, 2012, p. 453460).

${ }^{18}$ As características da psicopatia listadas por Cleckley (1941/1976) foram as seguintes: 1) Charme superficial e boa inteligência; 2) Ausência de delírios e outros sinais de pensamento irracional; 3) 
A classificação de transtornos mentais e de comportamento, em sua décima revisão (CID-10), descreve o transtorno específico de personalidade como uma perturbação grave da constituição caracterológica e das tendências comportamentais do indivíduo. Tal perturbação não deve ser diretamente imputável a uma doença, lesão ou outra afecção cerebral ou a um outro transtorno psiquiátrico e usualmente envolve várias áreas da personalidade, sendo quase sempre associada à ruptura pessoal e social.

Os transtornos de personalidade (TP) não são propriamente doenças, mas anomalias do desenvolvimento psíquico, sendo considerados, em psiquiatria forense, como perturbação da saúde mental. Esses transtornos envolvem a desarmonia da afetividade e da excitabilidade com integração deficitária dos impulsos, das atitudes e das condutas, manifestando-se no relacionamento interpessoal.

De fato, os indivíduos portadores desse tipo de transtorno podem ser vistos pelos leigos como pessoas problemáticas e de difícil relacionamento interpessoal. São improdutivos quando considerado o histórico de suas vidas e acabam por não conseguir se estabelecer. 0 comportamento é muitas vezes turbulento, as atitudes incoerentes e pautadas por um imediatismo de satisfação. Assim, os TP se traduzem por atritos relevantes no relacionamento interpessoal, que ocorrem devido à desarmonia da organização e da integração da vida afetivo-emocional. No plano forense, os TP adquirem uma enorme importância, já que seus portadores se envolvem, não raramente, em atos criminosos e, consequentemente, em processos judiciais, especialmente aqueles que apresentam características antissociais.

Por se tratarem de condições permanentes, as taxas de incidência e prevalência se equivalem na questão dos TP. A incidência global de TP na população geral varia entre $10 \%$ e $15 \%$, sendo que cada tipo de transtorno contribui com $0,5 \%$ a $3 \%$. Entre os americanos adultos, 38 milhões apresentam pelo menos um tipo de TP, o que corresponde a $14,79 \%$ da população.

Esse tipo de transtorno específico de personalidade é marcado por uma insensibilidade aos sentimentos alheios. Quando o grau dessa insensibilidade se apresenta elevado, levando o indivíduo a uma acentuada indiferença afetiva, ele pode adotar um comportamento criminal recorrente e o quadro clínico de TP assume o feitio de psicopatia.

Ausência de nervosismo e manifestações psiconeuróticas; 4) Não-confiabilidade; 5) Tendência à mentira e insinceridade; 6) Falta de remorso ou vergonha; 7) Comportamento anti-social inadequadamente motivado; 8) Juízo empobrecido e falha em aprender com a experiência; 9) Egocentrismo patológico e incapacidade para amar; 10) Pobreza generalizada em termos de reações afetivas; 11) Perda específica de insight; 12) Falta de reciprocidade nas relações interpessoais; 13) Comportamento fantasioso e não-convidativo sob influência de álcool e às vezes sem tal influência; 14) Ameaças de suicídio raramente levadas a cabo; 15) Vida sexual impessoal, trivial e pobremente integrada; 16) Falha em seguir um plano de vida (HAUCK FILHO; TEIXEIRA; DIAS, 2009, p. 337346). 
De tal sorte que no cometimento de delitos por psicopatas ${ }^{19}$, desde que se consiga identificá-lo como tal não resta muita dificuldade quanto a sua capacidade delitiva. Porém, a questão e razão deste tópico reside na questão fronteiriça, isto é, e para o indivíduo que não é psicopata, contudo, é um assassino, ou cometeu um delito de forma fria. Até que ponto a identificação das expressões faciais podem auxiliar o trabalho da justiça a fim de obter uma condenação no Tribunal do Júri? E mais: será que as expressões faciais e sua identificação podem ser mais eficazes que um detector de mentiras, o conhecido polígrafo, por exemplo?

A utilização das expressões faciais não é uma novidade no universo penal e, nos Estados Unidos da América, sua utilização é feita com frequência já há algumas décadas. Mas como pode ser útil a utilização da análise de expressões faciais?

No transcurso de uma investigação policial ao longo do inquérito é comum que os investigadores interroguem os suspeitos. Com a gravação e posterior análise desse vídeo por um profissional especializado em expressões faciais é possível identificar se há expressões dúbias, indícios de mentira ou uma suposta ocultação de verdade, o que podem contribuir para apurar ocultações por parte do suspeito e, inclusive, excluir um suspeito do rol de eventuais responsáveis pelo delito.

O cérebro humano não permite a presença de duas emoções simultaneamente, portanto, ao encobrir algum fato, ou tentar dissimular uma emoção o cérebro inconsciente manifesta outra, o que para um profissional experiente no tema pode identificar o que um investigador não consiga pela falta de expertise no tema. A presença de duas emoções, ainda que em um espaço de

\footnotetext{
${ }^{19}$ Os psicopatas costumam ser espirituosos e muito bem articulados, tornando uma conversa divertida e agradável. Geralmente contam histórias inusitadas, mas convincentes em diversos aspectos, nos quais eles são sempre mocinhos. Não economizam charme nem recursos que os tornem mais atraentes no exercício de suas mentiras. Outro sinal muito característico desse comportamento é a total falta de preocupação que esses psicopatas apresentam ao serem desmascarados como farsantes. Não demonstram a menor vergonha caso sejam flagrados em suas mentiras. Ao contrário podem mudar de assunto com a maior tranquilidade ou dar uma resposta totalmente fora de contexto. Esses tipos de psicopata são muito comuns no mercado de trabalho como um todo, que fingem serem profissionais qualificados, sem nunca terem colocado os pés numa faculdade. (...) Os Psicopatas mostram uma total e impressionante ausência de culpa sobre os efeitos devastadores que suas atitudes provocaram nas outras pessoas. Os mais graves chegam a ser sinceros sobre esse assunto: dizem que não possuem sentimento de culpa, que não lamentam pelo sofrimento que eles causaram em outras pessoas e que não conseguem ver nenhuma razão para se preocuparem com isso. Na cabeça dos psicopatas, o que está feito está feito, e a culpa não passa de uma ilusão utilizada pelo sistema para controlar as pessoas. Diga-se de passagem, eles (os psicopatas) sabem utilizar a culpa contra as pessoas "do bem" e favor deles com uma maestria impressionante. (SILVA, 2008, p. 63 e 67).
} 
milésimo de segundos pode revelar possíveis incongruências e, até mentiras. O cérebro quer, ao mesmo tempo, mentir e dizer a verdade.

Essas foram algumas das situações que foram abordadas no seriado Lie to $m e$, ao qual nos referimos mais cedo. Em um de seus episódios uma agente de segurança de aeroporto observa filas extensas de passageiros e, subitamente, caminha em direção a um dos viajantes. Ao abordá-lo, constata que o homem carrega uma mala cheia de dinheiro. Devido ao seu treinamento, o policial tem a capacidade de interpretar a expressão facial e a linguagem corporal do ser humano, e, assim, suspeitar de comportamentos e de indícios de irregularidades.

Como dissemos o seriado é baseado nos estudos de Paul Ekman e mostra o protagonista como "detector humano de mentiras" com a habilidade de ler a intenção do outro antes mesmo da pessoa se expressar em palavras ou concretizar o pensamento em ato.

Era comum na série desvendar crimes através da análise da expressão facial, linguagem corporal, voz e o modo de falar do suspeito.

O rosto é rico em potencial comunicativo, ocupando o primeiro lugar das zonas do corpo na comunicação dos estados emocionais. Alguns estudos alegam que isso se deve à nossa primeira infância, quando prestávamos muita atenção aos rostos que atendiam às nossas necessidades; outros, tentam demonstrar que muitas expressões faciais são inatas, independem de aprendizagem. Consideramos o rosto como a fonte primária de informações sobre as pessoas e provavelmente formulamos juízo acerca de sua personalidade por suas características faciais. Por exemplo, podemos ver uma pessoa parecida com alguém que já conhecemos, e apenas a partir dessa informação, inferir características de personalidade similares a ela. Também pelo rosto, definimos aproximadamente sua idade, etnia e gênero. Sabemos que o ser humano utiliza o rosto como um regulador das conversações, abrindo e fechando canais de comunicação (por exemplo, virando o rosto e desviando o olhar), complementando e qualificando outros sinais não verbais emitidos pelo indivíduo (quando dizemos "estou triste" e choramos), e em substituição a mensagens verbais, como por exemplo, quando alguém nos pergunta "gostou" e sorrimos, ao invés de falar (SILVA; SILVA, 1995, p. 80-87).

No Brasil sua prática ainda não é tão arraigada como nos Estados Unidos, mas, já é possível notar seu uso em alguns casos pela polícia brasileira. Na prática, no Estado de São Paulo foi criado um Grupo de Estudos de Neurociência na Atividade 
Policial (Neuropol), este formado por equipe multidisciplinar de nove delegados, especialistas em diversas áreas de conhecimento.

Com o treinamento é possível se avaliar a resposta de uma pessoa logo após a pergunta. E qual a diferença ou importância? São nos primeiros décimos de segundo após a pergunta que o ser humano responde espontaneamente, isto é, de forma automática, sem a presença da simulação. Assim, a cada nova pergunta o investigador tem o mesmo lapso temporal para avaliar o comportamento do interrogado em busca de mentiras através de suas expressões faciais.

Nesse intervalo a pessoa não consegue controlar suas emoções e transparece emoções reais, ainda que contra a sua vontade, mesmo que após esse mínimo intervalo a pessoa perceba e mude sua expressão facial ou corporal e criar um discurso que lhe seja favorável, o profissional consegue captar as mudanças de comportamento.

Uma pessoa pode tentar exprimir pesar, mas sua expressão facial denotar contentamento, ou forçar um argumento ensaiado a fim de corroborar com uma história ou um depoimento, mas, os especialistas podem encontrar discrepâncias em suas expressões faciais.

É possível aprender a se identificar o genuíno do "mascarado"20, uma mudança de olhar, um desvio, até a posição das mãos contribuem para o significado de seu comportamento ${ }^{21}$. Portanto, saber se o investigado está mentindo ou não pode mudar por completo o transcurso de uma investigação.

${ }^{20}$ Os Psiquiatras já admitem há muito tempo que o modo de um indivíduo movimentar o corpo oferece pistas sobre caráter, emoções e reações àqueles que o rodeiam. Durante anos, Felix Deutsch registrou os gestos e as poses de seus pacientes no divã. Outros Psiquiatras filmaram as sessões de análise e outros ainda concordaram em ser filmados ou observados enquanto cuidavam do cliente. Os terapeutas estão usando, cada vez mais, filmes e videoteipes para estudar o comportamento e como instrumental no processo de tratamento. Quando se defrontam com as suas próprias imagens no vídeo, os pacientes são estimulados a reagir diante da própria aparência e dos seus movimentos e a aprender com base em seu comportamento grupal, verbalizado ou não (DAVIS, 1979, p. 21).

${ }^{21}$ As posições das mãos no rosto são à base dos gestos humanos para enganar. Em suma, quando estamos para revelar uma mentira o corpo tende a levar as mãos para a face, seja na boca, olhos, nariz ou garganta. 1- Boca quando a criança mente costuma levar as mãos para cobrir a boa. O gesto de tapar a boca vem mais refinado no adulto. Quando o adulto diz uma mentira o cérebro automaticamente ordena à mão que tampe à boca para bloquear a saída das palavras falsas. 2- Nariz, o gesto de tocar o nariz é uma versão dissimulada de tocar a boca. Uma explicação é que quando a mente tem o pensamento negativo, o subconsciente ordena à mão que tampe a boca, mas, no último instante, para que não seja um gesto tão óbvio, a mão se retira da boca e toca o nariz. Outra explicação é que mentir produz coceira nas delicadas terminações nervosas do nariz e, para que passe, se faz necessário esfregá-lo. 3- Esfregar o olho, o gesto representa a tentativa do cérebro 
As expressões corporais podem auxiliar não apenas no transcurso do inquérito policial, como também para dirimir dúvidas que as próprias autoridades podem suscitar ao longo do processo, um novo aliado que incorpora a realidade do processo penal ${ }^{22}$, ainda que não regulamentado, mas muito útil na busca de respostas aparentemente inexistentes para os leigos.

Agora iremos refinar um pouco mais a questão das expressões faciais ao introduzir o tema das microexpressões.

\section{AS MICROEXPRESSÕES FACIAIS}

Não é de hoje que as microexpressões vêm sendo estudas, desde a pesquisa realizada por Darwin, muitos autores discutiram inúmeras teses sobre essa ciência, alguns concordavam com Darwin, mas a verdade é que grande maioria rebatia incessantemente seus estudos. Ao longo dos anos inúmeras questões foram travadas em face da ciência das microexpressões faciais, muitos autores lançaram diferentes teses quanto a veracidade das microexpressões e suas características, mas foi somente com os estudos de Ekman que muitas dessas questões foram respondidas.

Através das pesquisas de Ekman, a ciência das microexpressões faciais teve um avanço significativo, sendo sua teoria hoje considerada a de maior influência dentre todos os estudos, relacionadas ao tema.

Porém, ao contrário do que a maioria das pessoas acreditam, Paul Ekman não foi o primeiro a estudar as microexpressões faciais, na verdade as microexpressões foram descobertas por Haggard e Isaacs, no ano de 1966, enquanto digitalizavam filmes cinematográficos de horas de psicoterapia em busca de indícios de comunicação não verbal entre terapeuta e paciente, na época eles nomearam a descoberta como "micromomentâneas expressões faciais" e lançaram

bloquear a visão do engano ou de evitar ter que olhar a face da pessoa a quem está mentido. 4 Esfregar o pescoço, o gesto indica dúvida, incerteza e é característico da pessoa que não está concordando com algo. Ou também, quando estão mentindo tendem a puxar o colarinho da camisa, passar a mão na nuca e olham frequentemente para baixo (PEASE; PEASE, 2005, p. 22).

${ }^{22}$ A linguagem corporal auxilia na criação da empatia entre os participes da audiência, indispensável para que seja obtida a conciliação; em sentido contrário, pode estabelecer um clima de antipatia que impede o diálogo e com ele, a colaboração para uma solução amigável. A raiva e o medo são sentimentos na maioria das vezes, muito mais eficientemente transmitidos por meio de expressões faciais e corporais do que por meio de palavras. (MANZI, 2004, não paginado). 
sua descoberta ao mundo com a publicação do artigo "micro momentary facial expressions as indicators of ego mechanismis in psycotherapy".

Ekman iniciou suas pesquisas de campo em 1968, mas foi somente em 1976 que Ekman e Friesen desenvolveram a maior e mais importante ferramenta para identificação de microexpressões faciais ${ }^{23}$, a FACS $^{24}$ (Facial actioncoding system) que identifica músculos que não podem ser modificados espontaneamente, dos 44 que compõe a face, além de mimetizar uma expressão facial de uma emoção ativa a um processo fisiológico correspondente a tal emoção - qual já é utilizada há mais de 30 anos nos sistemas de justiça e segurança dos principais países, como por exemplo FBI e CIA (EUA); Scotland Yard (Inglaterra); e Interpol (União Europeia) ${ }^{25}$.

Marcos Roberto e Thiago Luigi, do Instituto de Microexpressão e linguagem corporal descrevem a FACS:

Essa ferramenta consiste em identificar os músculos que produzem as expressões faciais e separar as ações musculares faciais mais importantes nas expressões (micro e macro) em actionunits (unidades de ação ou AU's). Dessa forma, a ferramenta mede o relaxamento e contração do músculo, ou de um grupo muscular, e denomina em uma unidade, assim, tornando possível a visualização em intensidade, duração e assimetria (ROBERTO; LUIGI, 2017, p. 6).

Como já exposto, as emoções identificadas por Darwin (1872) e revistas por Ekman, em 1967/1968, são universais, pois, independentemente do viés cultural e

\footnotetext{
${ }^{23}$ O Facial Action Coding System (FACS) permite medir toda expressão facial ou comportamento facial visível, e não apenas aç̧ões que presumivelmente podem estar relacionadas a uma emoção. 0 instrumento distingue 44 unidades de acção, estas que são as unidades mínimas anatomicamente identificadas nos movimentos faciais. Este facto por si serve de recurso à avaliação da "espontaneidade" de uma expressão facial, analisando o tempo de reacção, duração e os músculos envolvidos na expressão, pode-se obter pistas para a sua interpretação. Obviamente, é preciso considerar outros factores que possam justificar as alterações do comportamento da face humana (DONATO et al., 1999).

${ }^{24}$ As evidências da universalidade das expressões faciais das emoções abriram um novo campo de possibilidades para a pesquisa sobre o comportamento não-verbal, no entanto, precisava-se de uma forma objectiva de explorar e comunicar esse conhecimento, era necessário ter-se um método que oferecesse aos cientistas comportamentais uma linguagem comum e um padrão objectivo de medição do comportamento em causa. Foi desta forma que Ekman e Friesen iniciaram uma das maiores empreitadas da pesquisa sobre o comportamento facial e construíram o primeiro instrumento que permite a análise e descrição objectiva dos movimentos dos músculos da face humana (DONATO et al., 1999).

${ }^{25}$ Essa ferramenta é usada atualmente por centenas de cientistas do mundo inteiro para pesquisas na área, e atualmente observa-se um esforço muito grande para automatizar em sistemas digitais essa ferramenta, para analisar faces em tempo real, como já vem ocorrendo nos grandes aeroportos, onde há o emprego de tal ferramenta na busca ininterrupta de possíveis terroristas e pessoas mal intencionadas. (AMARAL, 2017, p. 29).
} 
cognitivo, as expressões faciais são semelhantes e podem ser reconhecidas por qualquer pessoa, eis que possuem as mesmas funções dentro da comunicação interpessoal.

Sobre o tema Paul Ekman (2011, p. 37):

As emoções produzem mudanças nas partes do cérebro que nos mobilizam para lidar com o que deflagrou a emoção, assim como mudanças em nosso sistema nervoso autônomo, que regula o batimento cardíaco, a respiração, a transpiração e muitas outras alterações corporais, preparando-nos para diversas ações. As emoções também enviam sinais, mudanças nas expressões, na face, na voz e na postura corporal. Não escolhemos essas mudanças; elas simplesmente acontecem.

No mesmo sentido Marcos Roberto e Thiago Luigi (2017, p. 14):

Enquanto a maior parte dos músculos do corpo humano possui suas origens e inserções (seus pontos de apoio) nos ossos, os músculos superficiais da face estão ligados a outros músculos ou até mesmo à pele, o que permite a produção dos movimentos, macro e micro expressões da face, o que está diretamente relacionado com a capacidade humana de demonstrar emoções e de interagir no contexto social e profissional.

Tanto na pesquisa de Darwin quanto na pesquisa de Ekman na Nova Guiné, foram identificadas somente seis emoções universais (alegria ${ }^{26}$, raiva ${ }^{27}$, tristeza ${ }^{28}$,

26 Essa emoção está relacionada diretamente com sensações de excitação. É uma emoção diretamente positiva, pelo fato da pessoa que a vivenciar gozar de efeitos biológicos positivos. No contexto evolutivo, o display facial da alegria era responsável por comunicar para outras pessoas que emissor daquele sinal não verbal era amigo, não iria causar mal algum, era inofensivo, que era um deles. Essa expressão é caracterizada pela presença do sorriso na face humana, mas apenas esse sinal pode não caracterizar o sorriso verdadeiro. Uma pessoa verdadeiramente vivenciando a emoção de alegria irá apresentar um sorriso que percorrerá toda a extensão da face, contraindo os músculos ao redor dos olhos, o Orbicularis oculipar sorbitalis, que no FACS é agrupado na AU6 (ROBERTO; LUIGI, 2017, p. 18-19).

27 A raiva é uma das mais assustadoras Microexpressões, especialmente quando vê os sinais completos da raiva, sobrancelhas franzidas, olhar fixo, lábios pressionados um contra o outro ou abertos mostrando os dentes (rosnar), (ROBERTO; LUIGI, 2017, p. 27). Essa emoção tem seu display facial diretamente ligado à agressão, ao ataque. Um dos aspectos mais perigosos dessa emoção é que ela é cíclica, ou seja, pode gerar mais raiva e agravar rapidamente o ciclo. Interessante frisar que as causas da raiva podem ser as mais diversas possíveis, e não apenas um momento pré-combate, por exemplo, podemos sentir raiva de objetos, como um computador que travou, ou de comportamentos, como uma esposa sentindo raiva pelo marido ter bagunçado o quarto. (EKMAN, 2011).

${ }^{28}$ A tristeza é uma das emoções que possuem maior duração, e dependendo do fator externo que a provocou, como por exemplo, a morte de um filho, pode ter um display facial tão forte e potente que se assemelha à face de dor. Não apenas a face será de dor, como os efeitos no corpo também. Na face, a tristeza tem como carro chefe o AU1, que representa a movimentação do músculo Frontal parte interna, responsável por erguer a parte interna das sobrancelhas e com isso, produz rugas horizontais no centro da testa. Junto com ele podem aparecer outros AUs, como o AU15, por 
medo ${ }^{29}$, surpresa ${ }^{30}$, aversão/nojo ${ }^{31}$ ), a sétima emoção (desprezo ${ }^{32}$ ), somente foi identificada por volta do ano 2000 após novas pesquisas realizadas pelo Instituto Paul Ekman.

A ciência das microexpressões faciais também é uma forte aliada no trabalho de detecção de mentiras. Exceto na expressão do desprezo, todas as outras emoções possuem faces simétricas. A face simétrica simboliza a face verdadeira. Assim, uma

exemplo, que é o músculo depressor do ângulo da boca, responsável pela queda dos cantos da boca, resultando no arco labial para baixo, característico da tristeza. (EKMAN, 2011).

29 Para a neurologia, o medo é uma forma comum de organização do cérebro primário dos seres vivos, com a ativação da amígdala alojada no lóbulo temporal. Do ponto de vista da psicologia, o medo é um estado afetivo e emocional, necessário para o organismo se adaptar ao meio. Assim como a raiva o medo é uma das emoções mais selvagens do ser humano. São algumas características da microexpressão facial do medo, pálpebras superiores erguidas, sobrancelhas levantadas e juntas e boca esticada horizontalmente. Tendemos a esconder a emoção de medo suprimindo a reação ou mascarando o medo com outra emoção. O mais típico seria mascarar o medo com um sorriso, dessa forma é possível notar que após a microexpressão do medo, os cantos da boca sobem e um sorriso surge. (ROBERTO; LUIGI, 2017, p. 32 a 36).

30 A Surpresa é a emoção mais rápida de todas, durando no máximo alguns segundos após seu gatilho. Caso ela se estenda por muito mais que isso, é indicativo que a pessoa está mentindo a emoção, ou seja, fingindo estar surpresa com algo que não causou a emoção verdadeiramente. A surpresa é considerada uma emoção de transição, que dura alguns segundos, tempo necessário para o corpo entender o que está acontecendo, e absorver e processar o estímulo, ocorrendo então a transição para outra emoção, seja a raiva, tristeza ou alegria, por exemplo, como também pode ser sucedida de nenhuma emoção. Essa emoção só ocorre em casos de eventos súbitos e inesperados. Em relação à expressão facial, a surpresa é caracterizada pelo relaxamento total do tônus muscular facial, ou seja, o rosto popularmente fica "boquiaberto". (EKMAN, 2011).

31 O Nojo e Aversão, segundo Ekman (2011), apresentam o mesmo display facial e são consideradas uma única emoção pelo fato de causarem os mesmos efeitos no corpo de quem vivência a emoção. 0 nojo é a repulsa por estímulos físicos, como cheiros desagradáveis, excretos humanos, sujeira ou gostos, mas não somente a presença física de tais estímulos pode causar isso, é possível que apenas com a ideia, visão ou som deles a pessoa também experiencie sensações de repugnância, característica do nojo. 0 que muda em relação à aversão é que a repugnância é causada por uma pessoa, seja por seu físico, por sua personalidade, traços de comportamento ou até mesmo determinada ações. É possível sentir aversão de uma pessoa após vê-la maltratando um animal, por exemplo (EKMAN, 2011). Também se vê muito presente essa expressão na face de homofóbicos, racistas e preconceituosos no geral, ao terem contato com pessoas que possuem as características que thes causam aversão, como por exemplo, ter que cumprimentar um homem negro ou a um homossexual, ou até mesmo dependendo do grau de preconceito que a pessoa possui, a simples menção de determinada pessoa ou grupo traz à face tal expressão da emoção (ROBERTO; LUIGI, 2015b). Tanto no nojo quanto na aversão o AU principal é o 9 (ver 13), que se refere à junção das atividades do músculo Levantador do lábio superior e parte transversa do músculo Nasal, que em sua movimentação corrugam o nariz, produzindo rugas transversais no mesmo (ROBERTO; LUIGI, 2015a). (AMARAL, 2017, p. 41 e 42).

32 O desprezo é a mais nova das emoções, é uma emoção secundária e é uma mistura das emoções primarias nojo e raiva. Ao contrário das demais emoções, o desprezo é fruto da nossa racionalidade. O sentimento de desprezo ou superioridade pode ser um grande indicador da mentira. O desprezo é a única emoção assimétrica, parece um sorriso para si mesmo, pois só uma parte da sua boca vai para cima. Na verdade, isso não é um sorriso, e sim o sinal de que a pessoa está tendo pensamentos sobre a sua superioridade em relação a outras pessoas. Essa expressão está muito presente no rosto de assediadores morais e sexuais, após terem realizado o ato contra outra pessoa, sentindo-se assim, superiores em relação às suas vítimas. (ROBERTO; LUIGI, 2017, p. 41 a 43). 
das formas de se saber que alguém está mentindo é verificar a assimetria na expressão exposta na face.

Contudo,

Para uma correta deteç̧ão de mentira não basta a análise das expressões faciais, eis que quando uma pessoa mente ela apresente um conjunto de diferentes sinais (agitação; raiva; medo; vergonha; excitação e culpa, entre outros), assim, para analisar um mentiroso devemos observar tanto as micro e as macro expressões faciais, quanto a expressão corporal, caso contrário a análise poderá ser inconclusiva (ROBERTO; LUIGI, 2017, p. 9).

Sobre o funcionamento do cérebro ao longo da elaboração de uma mentira, observam Roberto e Luigi (2017, p. 9):

Nosso cérebro não aceita negação, assim, quando uma pessoa elabora uma mentira, está negando uma verdade, de forma que seu cérebro é obrigado a trabalhar duas ou três vezes mais para achar uma resposta falsa para aquela ocasião. O cérebro humano é sincero por isso por isso dificuldade em elaborar uma resposta falsa. É nesse momento da elaboração que o Sistema Nervoso Autônomo, deixa "vazar" na sua expressão facial e linguagem corporal a incongruência que não está de acordo com sua fala. Exemplos desses "vazamentos" que podem denunciar se a pessoa está mentindo são frequência de piscar os olhos, uso da sobrancelha para dar ênfase, posição das mãos, aspecto da testa e da boca ao morder ou pressionar os lábios, engolir seco, entre outros.

O sorriso é outra expressão facial que pode ajudar a perceber se uma pessoa está sendo falsa ou verdadeira. Em um sorriso sincero é nítida a contração das têmporas (músculo orbicular do olho), conhecido popularmente como pé de galinha. O que já não ocorre na demonstração de um sorriso falso. Importante frisar que nem todo sorriso falso pode ser apontado como mentiroso, o sorriso falso também pode ser classificado como sorriso social, que é aquele que normalmente damos no momento de uma foto ou ao cumprimentar outra pessoa.

No que se refere ao sorriso dentro das microexpressões faciais, é possível verificar três diferentes tipos. O sorriso Duchenne ${ }^{33}$, é o sorriso espontâneo -

33 Guillaume Duchenne de Boulogne (1806- 1875) foi um médico e neurologista francês. Suas contribuições para a medicina incluem os efeitos da utilização de eletricidade no ser humano, ativando determinados músculos isoladamente e estudando suas causas e consequências. O sorriso recebe seu sobrenome após experimentar a eletroestimulação do músculo Zigomático maior (o responsável pelo sorriso) de um paciente que havia perdido a sensibilidade à dor e ter percebido que tal paciente não vivenciava a emoção de alegria, mas quando algum estimulo o divertia de verdade, além do músculo Zigomático maior, o Orbicularis oculipars orbitalis (ou orbicular das pálpebras) também era ativado 
verdadeiro; o sorriso social ${ }^{34}$, é aquele sorriso intencional - falso, mas não necessariamente mentiroso; e o chamado "duping delight"35 ou prazer profundo, que é o sorriso que costuma se manifestar, espontaneamente, após uma mentira elaborada.

Os trabalhos de Paul Ekman se tornaram tão relevante que transcenderam as questões criminológicas e a passaram a ser utilizadas na medicina clínica a fim de identificar sintomas de depressão, dor, e para pessoas com o espectro do autismo. Todavia, as possibilidades se ampliam para outros ramos como o marketing e a identificação da recepção das pessoas e seus sentimentos ante a um produto.

Da mesma forma um professor treinado pode identificar as reações de seus alunos ao ministras suas aulas. A seguir listaremos alguns sentimentos e comportamentos que podem ser identificados a partir das expressões faciais ou modulações do próprio corpo, são elas: honestidade e desonestidade ${ }^{36}$, o tédio (Deixar que os olhos vagueiem; Olhar para longe; Ficar olhando para o relógio ou para outros objetos; Rabiscar; Apoiar o queixo na mão enquanto olha pela sala; Espreguiçar-se), atenção (Manter forte contato visual; Olhar fixamente para um objeto; Imobilidade geral; Inclinar ou balançar a cabeça; Coça a cabeça), frustração (Contato visual direto e frequente; Frases repetidas; Aproximação da outra pessoa, entretanto frequentemente em seu espaço pessoal; Gestos com as mãos; Apontar;

pelo cérebro. Estudo esse divulgado no livro "Mecanismo da Fisionomia Humana (1862)", ignorado por muitos anos até finalmente ser retomado em estudos pelo Professor Paul Ekman e Wallace Friesen, na década de 70 (AMARAL, 2017, p. 37).

${ }^{34}$ É o sorriso necessário para criarmos empatia nas pessoas mesmo que não vivenciamos a alegria verdadeira durante o encontro. Um exemplo quando se pede a uma criança que sorria para uma foto, esse sorriso será puramente social, ou seja, feito apenas para sair no retrato. $O$ sorriso social ou falso são intencionais e possuem assimetria, amplitude e duração diferentes (AMARAL, 2017, p. 37).

${ }^{35}$ É o prazer que o mentiroso tem ao acreditar que obteve sucesso em sua mentira. Alguns autores falam sobre as mentiras que são motivadas pelo desejo de obter uma sensação de poder, como por exemplo, a sensação de poder que vem de possuir informações que o outro não tem, de enganar o outro, ou impulsionar o interlocutor a tomar decisões erradas (Paul Ekman). Ford em seu livro Lies, lies, lies! The Psychology of Deceit, diz que o Duping Delight, pode resultar do sucesso de uma piada (em relação a alguém ou uma situação), ou pode ser motivado por formas malignas de engano, como trapaça ou por alguma patologia, como por exemplo a síndrome de Munchausen (ROBERTO; LUIGI, 2017, p. 21).

${ }^{36}$ Honestidade e a Desonestidade: Olhos que se movem muito e não se fixam; Qualquer tipo de inquietação; Fala rápida; Mudança na voz Balançar-se para frente e para trás sobre os próprios pés ou na cadeira; Qualquer sinal de nervosismo; Suor; Tremor; Qualquer movimento que esconda os olhos, boca, rosto, como colocar as mãos sobre os lábios, esfregar o nariz ou piscar os olhos; Passar a língua sobre os lábios; Passar a língua sobre os dentes; Inclinar-se para frente; Familiaridade inadequada, como bater nas costas, tocar outras partes do corpo e ficar perto demais (invadir o espaço pessoal) (DIMITRIUS; MAZZARELLA, 2009, p. 106). 
Dar de ombros), Depressão (Isolamento e fuga do contato social; Dificuldade de concentração; Dificuldade de se interessar por algo; Fala baixa e lenta; Corpo relaxado e frouxo; Esquecimentos; Movimentos lentos e deliberados), e nervosismo ${ }^{37}$ (DIMITRIUS; MAZZARELLA, 2009).

Ainda nesse tema temos, também, a identificação corporal e facial de emoções: Afeição/Amor: fixação do olhar com pupila dilatada; "olhar brilhante': "endireitamento" do nariz; Alegria/Prazer: rubor facial, levantar pálpebras, sorriso, gargalhada, beijos, "olhar brilhante"; Ansiedade: suor na região frontal, palidez, rugas na fronte, mordiscar os lábios ou cutícula; Dor/Incômodo: choro, olhos fechados, rugas na testa, lábios comprimidos, aumento da rigidez facial, comissura da boca para baixo, suor frio; Dúvida: "lábios em bico", inclinar lateralmente a cabeça , erguendo as sobrancelhas; Interesse: olhar na direção do objeto ou da pessoa, sorriso, meneio positivo da cabeça; Medo: pálpebras fechadas rapidamente, ou abrindo-se excessivamente, expressão "seria" e rígida, franzi menta dos lábios; Raiva/Ódio: rubor da face, dentes e maxilar cerrados, protrusão dos lábios, enrugamento da pele ao redor dos olhos, olhar fixo no objeto da raiva, com pupila contraída; Surpresa: abertura da boca e dos olhos, erguendo as sobrancelhas; Timidez Vergonha: rubor na face, abaixar os olhos, mudança do foco do olhar, leve protrusão da língua, observação através dos cílios; Tristeza: comissura da boca voltada para baixo, sobrancelhas oblíquas, "olhar cabisbaixo", choro (SILVA; SILVA, 1995).

Ainda, algumas emoções podem ser características de determinado tipo de criminoso, sendo que algumas microexpressões podem até se tornar parte da linha de base dessas pessoas. A linha de base é o comportamento habitual daquele ser humano, é possível que uma pessoa tenha mais de uma linha de base facial, por exemplo, seu comportamento habitual no ambiente familiar é diferente do seu comportamento habitual no seu ambiente de trabalho, assim, é bem possível que em cada um desses ambientes seja utilizada uma linha de base diferente. Existe também

\footnotetext{
37 Tensão no corpo curvar-se; Passar o peso do corpo de um lado para o outro; Balançar na cadeira; Cruzar e descruzar os braços e pernas; Tamborilar com as mãos, dedos e pés; Arrumar ou brincar com canetas, copos, óculos, joias, roupas, unhas, cabelos, mãos etc.; Retorcer as mãos; Limpar a garganta; Tossir de modo nervoso; Morder os lábios; Tagarelar nervosamente; Colocar as mãos nos bolsos; Ficar em silêncio. (DIMITRIUS; MAZZARELLA, 2009, p. 116).
} 
a chamada linha de base fixa, essa é aquela que reflete o caráter de uma pessoa, e é essa linha de base física que muitas vezes pode ajudar a identificar um criminoso.

Dentro desse contexto podemos citar alguns exemplos mais comuns. Uma linha de base fixa que demonstra a expressão da raiva junto com a expressão da aversão, costuma ser característica encontrada em "massmurderers 38 (assassinos em massa) e "spreekillers"139. Os psicopatas (serial killers) possuem em sua linha de base o "smart face" também conhecido por alguns especialistas como "sorriso do coringa", essa expressão facial é caracterizada pela Unidade de Ação - AU13 - é o sorriso sarcástico, e apesar de quase imperceptível, fica estampado no rosto dessas pessoas. Também pode ser verificado em estupradores, pedófilos, terroristas, assediadoras e homicidas.

O "dumping delight", que já foi explicado acima, costuma aparecer em mentirosos compulsivos e políticos. Já a emoção do desprezo costuma estar presente na face de viciados em álcool e drogas, pessoas que ocultam informações, pessoas manipuladoras e mentirosas, pessoas que praticam assédio moral e sexual e nos psicopatas. Por fim, a emoção da aversão também costuma estar presente na face de viciados em álcool e drogas, além de racistas, homofóbicos e preconceituosos em geral.

\footnotetext{
${ }^{38}$ FBI - Federal Bureau of Investigation - que considera estarmos perante um assassino em série, se este cometer "três ou mais eventos separados, com um período de acalmia emocional entre os homicídios, ocorrendo cada crime num local diferente". Já para o National Institute of Justice (agência que faz parte do departamento de justiça dos Estados Unidos da América), para se poder falar de assassino em série, este tem que ter perpetuado "uma série de dois ou mais homicídios, cometidos como eventos separados, normalmente, mas nem sempre, cometidos por um criminoso que atua sozinho. Os crimes podem ocorrer durante um período que varia entre horas e anos. Quase sempre o motivo é psicológico e o comportamento do criminoso, bem como as provas físicas encontradas nos locais do crime terão uma conotação sádica e sexual". (SCHECHTER; EVERITT, 2010, p. 103-104).

39 O termo serial killer não se refere a qualquer tipo de assassino. Não é igual também ao assassino em massa (ou spree killer), que mata indiscriminadamente grande número de pessoas como visto por exemplo no incidente da escola de Columbine. A característica que marca o serial killer como tal é precisamente a que lhe dá o nome: a serialidade das mortes. Essas se inserem em uma sequência na qual qualquer das partes pode ser substituída por qualquer outra. Dentro das propriedades comuns de cada série, qualquer de seus elementos é intercambiável. (GORENDER, 2010). O Spree Killer que costuma ser confundido com o Serial Killer, mas "as vítimas dele estão no lugar errado, na hora errada. O criminoso mata várias pessoas num período de horas, dias e semanas, e não passa por fases e se acalma até precisar matar novamente". A diferença entre o Spree Killer e o Serial Killer é que este planeja seu ato e tem a vítima padrão, enquanto aquele escolhe qualquer uma e mata. (SILVA, 2018).
} 


\subsection{Expressões faciais $x$ Microexpressões faciais}

E, afinal qual a diferença para uma expressão facial, para uma microexpressão facial? Quando uma emoção acontece, sem que exista qualquer motivação para modificá-la ou escondê-la, esta dura entre 0,5 a 4 segundos e envolve a face como um todo, o que pode ser denominada de macroexpressão facial. Já as microexpressões são expressões que perfazem a face de tempo em tempo em um lapso de fração de segundo, às vezes tão rápidas quanto $1 / 30$ de um segundo ${ }^{40}$. Sua percepção depende da utilização de gravações para que seja possível voltar, analisar, rever a fim de identificar corretamente a mesma.

Sem um treinamento adequado uma pessoa pode simplesmente não perceber ou mesmo reconhecer uma microexpressão em tempo real. E como que a microexpressão, em geral, acontece? Quando um indivídio precisa controlar suas expressões ainda que em situações emocionais intensas, involuntariamente ativa-se os sistemas piramidal e extrapiramidal o que ocasiona um lapso de controle neural da face, o que resulta em um vazamento rápido e passageiro das micrexpressões, ou melhor, em situações de stress há um conflito neural entre o sistema emocional e o cognitivo, que propiciam manifestações físicas quase imperceptíveis.

De tal sorte que o uso especializado das microexpressões resulta em ganhos claros para as atividades policiais, identificação de discrepâncias, saneamento de dúvidas, e, inclusive o descarte de um suspeito pela análise tanto das expressões faciais como de suas microexpressões faciais.

Assim, na criminologia, as microexpressões faciais são instrumentos auxiliares na investigação de crimes, como por exemplo, na investigação de homicídio porque a face da vítima de homicídio permanece com a expressão de sua última emoção, assim é possível descobrir se uma pessoa foi assassinada ou se suicidou, pois a expressão daquele que cometeu suicídio é sempre uma expressão de tristeza, normalmente apática, já a pessoa assassinada costuma demonstrar na face a emoção do medo, que, associada à expressão de aversão, pode significar que a vítima conhecia seu homicida.

40 Movimentos faciais muito rápidos, que duram menos de um quinto de segundo, [que] são uma importante fonte de vazamento, revelando a emoção que a pessoa está tentando dissimular (tradução livre). (EKMAN, 2007. p. 15). 
As microexpressões ainda são mais utilizadas por sistemas de segurança e justiça, porém, são aplicáveis a qualquer pessoa e em meio a qualquer relação. O conhecimento da análise de emoções através das microexpressões faciais podem melhorar em inúmeros aspectos a vida de uma pessoa. Por exemplo, ao detectar uma expressão de raiva, você pode anteceder os acontecimentos e evitar algum tipo de agressão ou violência. Ao detectar a expressão do desprezo é possível se manter longe daquele colega de escola ou trabalho que com certeza praticaria bullying contra você. É possível até aplicar a análise das microexpressões faciais para se sair bem em uma entrevista de emprego.

Esse conhecimento pode aumentar a inteligência emocional, melhorar a qualidade de seus relacionamentos, desenvolver habilidades sociais, detectar quando alguém está sendo falso com você e inúmeras outras situações que com certeza agregarão positividade na vida daquele que a utiliza no dia a dia.

\section{A CRIMINOLOGIA, O PROCESSO PENAL E AS MICROEXPRESSÕES FACIAIS}

A criminologia tem se beneficiado sobremaneira com o avanço das pesquisas sobre o uso e identificação das expressões faciais e, igualmente, com as microexpressões faciais. Casos de solução complexa, com dificuldades de eliminação de suspeitos, ou, inclusive, de determinação do mesmo tiveram um novo alento com essa técnica e seu desenvolvimento.

A tecnologia também contribuiu, com a criação de softwares que fazer o reconhecimento das microexpressões e identificam as discrepâncias. Além disso, alguns países como os Estados Unidos da América investiram em alta escala em programas de reconhecimento facial, mais notadamente após os atentados terroristas de 2001.

O Federal Bureau of Investigation - FBI faz uso do programa Next Generation Identification (NGI). Esse sistema é capaz de analisar mais de 411 milhões de fotos para identificar suspeitos. Além disso também tem a capacidade de analisar além dos rostos de pessoas que já cometeram crimes, como também comparar a pesquisa com fotografias de vistos e passaportes. 
A Rússia também fez muito bom uso da tecnologia e criou através da empresa NTechLab um software de reconhecimento facial que pode ser usado em conjunto com câmeras de vigilância a fim de identificar pessoas nervosas, em estado de irritação ou até estressadas em uma multidão, como forma de prevenir crimes em tempo real.

Essa mesma empresa já havia desenvolvido, com sucesso, outro software em 2016 para encontrar pessoas desaparecidas, com uso da tecnologia integrada a um aplicativo, o FindFace, através de uma rede social específica, a VKontakte.

De volta ao transcurso de uma investigação policial ou mesmo ao longo de um processo penal temos dois elementos que, em geral, são correlacionados: a busca pela verdade e a eliminação da mentira. Para tanto, os profissionais da justiça se utilizam de métodos e elementos a sua disposição a fim de dirimir mentiras e se aproximar ao máximo da verdade a fim de responsabilizar os culpados por seus delitos, dentre eles podemos listar interrogatórios, oitiva de testemunhas, contraditas, as microexpressões faciais e, por vezes, outro elemento que ainda não apresentamos, por não ser tão usual no cotidiano da justiça penal: o polígrafo ${ }^{41}$.

Mário Rui Carvalho Barbosa (2012, p. 22) sobre o polígrafo:

O Polígrafo é usado para a gravação de alterações de fenómenos fisiológicos, tais como: a frequência cardíaca, pressão arterial, condutividade da pele, taxa de respiração, alterações na voz, etc. Estes fatores são analisados, porque são tidos como involuntários. Estão fora do controlo humano aquando da interrogação. A informação de todos os parâmetros é correlacionada e analisada em questões específicas. Os especialistas do teste com esta informação afirmam saber se o sujeito está ou não a mentir.

Sua utilização é bastante controvertida na justiça visto que seus resultados não são uma garantia absoluta de sucesso e eficácia, visto que a validade é

\footnotetext{
${ }^{41}$ William M. Marston, psicólogo e criador da personagem Wonder Woman 1, que é caracterizada pela procura da verdade e justiça social, teve uma ideia de criar um instrumento que conseguisse detectar mentiras. Em 1915 enquanto estudante de pós-graduação da Universidade de Harvard reportou que a pressão sanguínea aumenta quando as pessoas mentem. A premissa anteriormente mencionada, ajudou à invenção do polígrafo, detector de mentiras, em 1920 por J. A. Larson, estudante de medicina na Universidade de Califórnia em Berkeley e por L. Keller, polícia do departamento Berkeley na Califórnia. Os polígrafos são utilizados por agências relacionadas com justiça e lei, no setor privado para rastreio pré-emprego e para testes de espionagem e sabotagem[1]. Os proponentes alegam que o teste do polígrafo atinge altas taxas de sucesso, $98 \%$ para sujeitos culpados e $82 \%$ para sujeitos inocentes. Estas taxas são elevadas pelo facto de serem deixados de fora casos inconclusivos. (BARBOSA, 2012, p. 21).
} 
questionável $^{42}$ quanto as reações fisiológicas ao teste em si, com pessoas que possuem, inclusive, treinamento especializado para enganar ou ludibriar o polígrafo.

Além da perícia, das provas, por óbvio, a linguagem corporal, as expressões faciais e as microexpressões faciais e os instrumentos de sua detecção são o caminho que contribuem para a justiça penal, seu aprimoramento, conhecimento das técnicas tem tudo para contribuir sobremaneira com os já existentes métodos de investigação.

O que resta, em especial ao Brasil, é a questão do investimento financeiro. Enquanto não for gasto erário a fim de capacitar os profissionais para a detecção das microexpressões, o aporte científico com intercâmbio e estudo de novas técnicas, a justiça penal ainda poderá carregar consigo a insígnia da dúvida e dirimi-la ainda custará um tempo maior do que se as expressões faciais fosses incorporadas ao processo.

Ademais, faltam os procedimentos, pois, não sua previsão no Código de Processo Penal como um dos meios válidos como obtenção de prova, portanto, depende da liberalidade de cada Magistrado em autorizar ou não sua utilização no transcurso do processo. Aos mais liberais haverá a defesa de que o artigo 155 do Código de Processo Penal ${ }^{43}$ autoriza todos ${ }^{44}$ os meios de prova ${ }^{45}$ desde que obtidos

\footnotetext{
${ }^{42}$ A produção científica mostra que a preocupação com a detecção de fraudes não é nova. O polígrafo é um instrumento concebido para a "detecção de mentiras", através da avaliação da tensão e pulsação dos dedos que se mostram ser bons indicadores para a medição do stress fisiológico. Deste modo, alterações no ritmo desta tensão e pulsação tomadas como linha de base significariam sinais de elevação de stress (associado a mentira), activando-se deste modo uma pequena descarga como um estímulo desagradável (punição). Contudo, as reacções fisiológicas ao teste em si são consideradas problemáticas, pelo que a sua validade é questionável. (LANSLEY, 2014).

${ }^{43}$ Art. 155. O juiz formará sua convicção pela livre apreciação da prova produzida em contraditório judicial, não podendo fundamentar sua decisão exclusivamente nos elementos informativos colhidos na investigação, ressalvadas as provas cautelares, não repetíveis e antecipadas (NUCCI, 2011).

${ }^{44}$ São basicamente três sistemas: a) livre conviç̧ão: é o método concernente à valoração livre ou à íntima convicção do magistrado, significando não haver necessidade de motivação para suas decisões. É o sistema que prevalece no Tribunal do Júri, visto que os jurados não motivam voto; b) prova legal: é o método ligado à valoração taxada ou tarifada da prova, significando o preestabelecimento de um determinado valor para cada prova produzida no processo, fazendo com que o juiz fique adstrito ao critério fixado pelo legislador, bem como restringido na sua atividade de julgar. Era a época em que se considerava nula a força probatória de um único testemunho (unus testis, nullus testis ou testis unius, testis nullius). Há resquícios desse sistema, como ocorre quando a lei exigir determinada forma para a produção de alguma prova, v.g., art. 158, CPP, demandando o exame de corpo de delito para a formação da materialidade da infração penal, que deixar vestígios, vedando a sua produção através da confissão; c) persuasão racional: é o método misto, também chamado de convencimento racional, livre convencimento motivado, apreciação fundamentada ou prova fundamentada. Trata-se do sistema adotado, majoritariamente, pelo processo penal brasileiro, que encontra, inclusive, fundamento na Constituição Federal (art. 93, IX), significando a permissão dada ao juiz para decidir a
} 
licitamente. Todavia não há previsão nesse ordenamento a figura da análise comportamental.

Tal atividade não pode ser confundida com uma perícia, e, tampouco, com interrogatório ou outro instrumento previsto como meio de obtenção de prova, porque simplesmente sua figura jurídica é alienígena. Temos como meio de obtenção de prova: documentais, periciais, testemunhais. Novamente um entusiasta poderia se fazer valer da prova oral, mas, na prática não é o caminho mais adequado.

O técnico em análise comportamental deve ser equiparado a um perito, ainda que respeitadas suas diferenças e expertises técnicas. Em juízo, com a devida regulamentação, poderá se utilizar do técnico quando do interrogatório do acusado a fim de detectar possíveis incongruências e/mentiras através das microexpressões faciais. E não se pode alegar que o art. 159 do Código de Processo Penal o autoriza a participar como assistente técnico, pois, as funções além de diversas não se confundem ${ }^{46}$, visto que o perito analisa os vestígios, os documentos, este funciona como um "assessor técnico processual" para sua correta elucidação e instrumentalização ${ }^{47}$. A perícia não se confunde com a análise comportamental, sobre a perícia Fernando da Costa Tourinho Filho (1999, p. 360):

Perícia é o exame procedido por pessoa que tenha certos conhecimentos técnico, científicos, artísticos ou práticos acerca dos fatos, circunstâncias ou condições pessoais. Além da perícia médicolegal, uma das mais importantes, há uma variedade imensa de perícias sobre as pessoas para determinar idade, sexo, altura, sanidade mental, doenças venéreas etc. Há perícias para constatar, por exemplo, se o projétil foi disparado por esta ou por aquela arma, para saber se uma arma foi disparada recentemente, se determinada mancha foi provocada por sangue e se este sangue é humano.

causa de acordo com seu livre convencimento, devendo, no entanto, cuidar de fundamentá-lo (NUCCI, 2011, p. 357).

45 O termo prova origina-se do latim - probatio - que significa ensaio, verificação, inspeção, exame, argumento, razão, aprovação ou confirmação. Dele deriva o verbo provar - probare - significando ensaiar, verificar, examinar, reconhecer por experiência, aprovar, estar satisfeito com algo, persuadir alguém a alguma coisa ou demonstrar (NUCCI, 2011, p. 356).

46 Admite-se que a parte, durante o curso do processo, ofereça assistentes técnicos, ainda que o prazo regulamentar tenha sido ultrapassado (art. 159, $\S 4^{\circ}$ ). Portanto, o correto é, assim que o perito oficial começar a elaborar o seu exame, as partes apresentarem quesitos e indicarem assistentes. (NUCCI, 2011, p. 392).

47 Perito é a pessoa que, por sua especial aptidão, realiza a perícia, acerca de pessoas, fatos e coisas. O perito assessora tecnicamente o Juiz. É como se fora os óculos de grau do Magistrado e por onde este vê o que normalmente não lhe seria lícito fazê-lo. De todas as perícias que podem ser feitas ressalta uma de excepcional importância, o exame de corpo de delito. (TOURINHO FILHO, 1999, p. 360-361). 
Em que pese sua parca utilização no direito brasileiro, o uso das microexpressões faciais carece de regulamentação e, mais do que isso, de procedimentalização, tanto para garantir a segurança do sistema em si como para proteger o acusado, a vítima e validar sua análise no processo penal.

O devido processo legal não pode estar à mercê da boa vontade de um magistrado em admitir um novo meio de prova. Não se pode encarar como uma exceção, mas sim, como algo novo que deve ser estudado e incorporado ao ordenamento. E não basta apenas e tão somente criar uma lei que autoriza a utilização do técnico em análise comportamental como validação de prova processual, pois, sem os limites e parâmetros o método pode ser usado de forma equivocada.

\section{CONCLUSÃO}

O ser humano é capaz de feitos notáveis como, inclusive, dissimular suas próprias emoções a fim de mascarar um comportamento ou evitar uma responsabilização ou associação com algum delito. Tal comportamento é uma mentira? Parcialmente verdade, pois, o que se busca é mascarar a verdade, Paul Ekman, em seus estudos sobre a personalidade e comportamento humanos afirma: "A mentira é uma característica tão central na vida, que um melhor conhecimento desta será relevante para a compreensão de quase todos os comportamentos humanos" (EKMAN, 2011, p. 85).

De posse de um conhecimento que antecede a Charles Darwin, os especialistas comportamentais buscam elucidar o comportamento humano e traduzilo a algo mais próximo da realidade, eliminando, portanto, as eventuais mentiras arraigadas no cotidiano. E qual a efetividade prática de um procedimento como esse?

O primeiro e mais preponderante é se evitar que um inocente possa ser responsabilizado de forma equivocada por uma apuração decorrente da perícia e das provas colacionadas no transcurso da investigação.

As atividades policiais nem sempre investigam tão a fundo quando já encontram um primeiro suspeito e passam a analisar os fatos de acordo com esse 
indivíduo. Com os analistas comportamentais é possível verificar se o depoimento é incongruente ou se o que o investigador concluiu não condiz com o depoimento em si.

Com o estudo das expressões faciais, a ciência propicia a compreensão das emoções e sentimentos dos seres humanos - adultos ou crianças, e, inclusive dos animais. Colocado à margem o aspecto criminológico, o estudo das expressões faciais possibilita um melhor entendimento de pessoas e situações que podem evitar situações, constrangimentos ou mensagens interpretadas de maneira equivocada.

Assim, no ambiente de trabalho, uma importante reunião pode ter outro desfecho se uma pessoa aprende a "ler" as reações do seu chefe. No ambiente familiar, lidar com um bebê pode ser uma tarefa complexa por falta de compreensão das reações do pequeno.

O conhecimento sobre as expressões das emoções e seu significado beneficiam as relações interpessoais, com o desenvolvimento de inteligência emocional, de uma consciência interna, incremento de empatia e redução de vulnerabilidade.

Como já dissemos, no ambiente jurídico seus ganhos são evidentes, mas também para os médicos e a interpretação das dores dos pacientes, na educação na relação professor e aluno, são apenas algumas das possibilidades para o uso e interpretação das expressões faciais.

Para esse nosso estudo o que nos importa é a criminologia, portanto, o impacto das expressões faciais no cotidiano da justiça penal e de seus métodos investigativos. E os problemas são vários quando se há um abismo entre a realidade envolvida cada vez mais pela tecnologia em contraposição a um Código de Processo Penal elaborado em tempos pretéritos e cindidos dessa modernidade.

De tal sorte que não há qualquer tipo de previsão legal para o uso ou admissão em juízo no transcurso de um processo penal a análise das microexpressões faciais e suas particularidades. Assim, fica restrito ao livre-arbítrio dos Magistrados caso a caso possibilitar seu uso ou não.

Os erros judiciais existem, o ser humano é criativo e sabe lidar muito bem com a mentira, uns mais e outros menos. Portanto, o trabalho policial pode ser equivocado, pode apontar para um suspeito que, em verdade é inocente, mas que 
foi apurado como o autor do delito por falta de uma maior expertise dos envolvidos ou por já terem atribuído a autoria ao primeiro suspeito sem maiores investigações para outros possíveis infratores.

A análise comportamental, especificamente das microexpressões faciais, podem contribuir sobremaneira para corrigir esses problemas, pois através de análise dos depoimentos dos envolvidos se pode detectar incongruências e reações que um olhar destreinado simplesmente é incapaz de notar.

Admitir a interpretação das expressões e microexpressões faciais podem representar um ganho para a justiça penal brasileira, desde que devidamente procedimentalizada, com suas atividades bem estabelecidas, para que assim se evite o dispêndio errôneo de erário ou seu mau uso.

As microexpressões faciais são uma realidade que o legislador tupiniquim ainda insiste em ignorar e não regulamentar. Já é mais do que momento do Governo Federal capacitar seus agentes através de uma força tarefa ou um grupo de análise comportamental em número qualitativo e quantitativo capaz de funcionar de maneira prática eficaz e que possa, de fato, contribuir com o cotidiano processual penal brasileiro e não em casos esparsos por falta de recursos ou de pessoal. Investir na correta investigação é valorizar o primado fundamental do Direito: a justiça.

O sistema processual penal brasileiro carece de reformas, de aperfeiçoamento e, principalmente, de uma melhor procedimentalização de suas normas e regras processuais penais que, atualmente, não conseguem sequer evitar que uma pessoa fique presa mesmo já tendo cumprido sua pena, ou cumprir por anos uma prisão preventiva, para posteriormente se apurar sua inocência.

As microexpressões faciais devem ser parte do conjunto probatório brasileiro, que se apure o culpado sem o risco de se prender um inocente por falta de uma investigação mais bem instrumentalizada. A justiça agradece, o erro é evitado e o Processo se aprimora, resta saber se há o devido interesse do Estado Democrático de Direito Brasileiro em garantir e efetivar os direitos fundamentais a seus cidadãos.

O ordenamento jurídico de um país existe e é criado para garantir a paz social e a convivência harmônica entre seus integrantes em determinado espaço dentro de um lapso temporal determinado e cabe a esse Estado Democrático aperfeiçoar o sistema, corrigir as imperfeições e sempre aprimorar seu próprio 
ordenamento a fim de garantir que a sociedade se aproxime da justiça e da equidade entre seus membros.

Não pode o Estado se quedar inerte na questão das microexpressões, os erros de uma investigação não podem se perpetrar por falta de investimento, o Governo Federal pode e deve modernizar seus meios investigativos pela bem da própria sociedade democrática brasileira e pela defesa dos interesses dos cidadãos brasileiros.

\section{REFERÊNCIAS}

AMARAL, Lucas Martins. A FACE DO MAL: Um estudo sobre a habilidade de pessoas comuns e sem treinamento em perceber e interpretar micro expressões pré-hostis. Monografia (Bacharelado em administração) - Escola Superior de Propaganda e Marketing. São Paulo, 2017.

BARBOSA, Mário Rui Carvalho. Estudo e Contextualização do Polígrafo quanto à Análise de Voz, ECG e EDR. 2012. 110 f. Dissertação (Mestrado Integrado em Engenharia Electrotécnica e de Computadores) - Faculdade de Engenharia, Universidade do Porto, 2012.

COSTA-VIEIRA, Hélida Arrais Wânia; SOUZA, Cristina de. O reconhecimento de expressões faciais e prosódia emocional: Investigação preliminar em uma amostra brasileira jovem. Revista Estudos de Psicologia, Natal, v. 19, n. 2, p. 89-156, abr./jun. 2014.

CUVE, Hélio Clemente José. Expressões faciais das emoções e microexpressões: Potencialidades da Psicologia moderna para Moçambique. Maputo, 25 abr. 2015. Disponível em: http://ceapuem.blogspot.com/2015/04/expressoes-faciaisdasemocoes-e-micro.html. Acesso em 31 de maio de 2018.

DARWIN, Charles. The expression of the emotions in man and animals. London: John Murray, 1872. Disponível em: http:// darwin-online.org.uk/. Acesso em: 31 maio 2018.

DAVIS, Flora. A comunicação não-verbal. 5. ed. São Paulo: Summus, 1979.

DAVOGLIO, Tárcia Rita et al. Personalidade e psicopatia: implicações diagnósticas na infância e adolescência. Revista Estudos de Psicologia, Natal, v. 17, n. 3, p. 453460 set./dez, 2012.

DIMITRIUS, Jô-Ellan; MAZZARELLA, Wendy Patrick. Decifrar Pessoas: como entender e prever o comportamento humano. 2. ed. Rio de Janeiro: Elsevier, 2009. 
DONATO, Gianluca et al. Classifying Facial Actions. IEEE transactions on pattern analysis and machine intelligence, [s.I.], v. 21, n. 10, out. 1999. Disponível em: http://citeseerx.ist.psu.edu/viewdoc/summary?doi=10.1.1.8.991. Acesso em: 3 jun. 2018.

EKMAN, Paul. A lingua franca of facial expressions. Demos, [s.I.], n. 10, p. 37-38, 1996.

. A linguagem das emoções. São Paulo: Lua de Papel, 2011.

Emotions revealed: recognizing faces and feelings to improve communication and emotional life. 2. ed. New York: St. Martin's Griffin, 2007.

. Facial expressions. In: DALGLEISH, Tim; POWER, Mick. Handbook of Cognition and Emotion. New York: Wiley, 1999. p. 301-320.

. Facial expression and emotion. American Psychologist, Washington, DC, v. 48, n. 4, p. 384-392, 1993.

. Should We Call it Expression or Communication? Innovations in Social Science Research, [s.I.], v. 10, n. 4, p. 333-344, 1997.

. The argument and evidence about universal in facial expressions of emotion. In: WAGNER, H.; MANSTEAD, A. (ed.). Handbook of social psychophysiology. Manchester: John Wiley \& Sons Ltd, 1989. p. 143-164.

. Universal Facial Expressions of Emotions. California Mental Health Research Digest, California, v. 8, n. 4, p. 151-158, 1970.

EKMAN, Paul; FRIESEN, Wallace V. A new pancultural facial expression of emotion. Motivation and Emotion, [s.I.], v. 10, n. 2, p. 159-168, 1986.

EKMAN, Paul; FRIESEN, Wallace V.; ELLSWORTH, Phoebe. What emotions categories or dimensions can observes judge from facial behavior? In: EKMAN, Paul (ed.).

Emotions in the human face. New York: Cambridge University Press, 1982. p. 3955.

EKMAN, Paul; MATSUMOTO, David R.; FRIESEN, Wallace V. Facial expression in affective disorders. In: EKMAN, Paul; ROSENBERG, Erika L. (ed.). What the Face Reveals. New York:

Oxford University Press, 1997. p. 331-342.

FEITOSA, Maria Ângela Guimarães. Resenha: Darwin, o comportamento humano e as emoções. Revista Psicologia: teoria e pesquisa, Brasília, DF, v. 15, n. 3, p. 265267, set./dez. 1999.

FREITAS-MAGALHÃES, A. A Psicologia das emoções: o fascínio do rosto humano. Porto: Feelab Science Books, 2013. 
O código de Ekman: o cérebro, a face e a emoção. Porto: Universidade Fernando Pessoa, 2011.

GORENDER, Miriam Elza. Serial killer: o novo herói da pós-modernidade. Revista Estudos de psicanálise, Belo Horizonte, n. 34, p. 117-122, dez. 2010.

HAUCK FILHO, Nelson; TEIXEIRA, Marco Antônio Pereira; DIAS, Ana Cristina Garcia. Psicopatia: o construto e sua avaliação. Revista Avaliação Psicológica, Porto Alegre, v. 8, n. 3, p. 337-346, dez. 2009.

JAMES, Judi. Linguagem corporal no trabalho. Rio de Janeiro: Best Seller, 2008.

LANSLEY, Clliff.. Lie to me. [S.I]: DPG plc Professional Development Conference, 2014. 1 vídeo (11 min). Disponível em:

https://www.youtube.com/watch?v=RnwdndsspTI. Acesso em: Acesso em: 31 maio 2018

MATSUMOTO, David; HWANG, Hyi. Science Brief: Reading facial expressions of emotion: basic research leads to training programs that improve people's ability to detect emotions. Psychological Science Agenda: [s.n.], 2011.

MANZI, José Ernesto. O Uso de Técnicas Psicológicas na conciliação e na colheita de prova judiciária. Jus.com.br, [S.I], maio 2004. Disponível em:

htpp://jus.com.br/revista/texto/5243/o-uso-de-tecnicas-psicologicas-na-conciliacaoena-colheita-da-prova-judiciaria. Acesso em 31 de maio de 2018.

MATSCHNIG, Monica. Linguagem corporal. Tradução: Fernanda Romero. Petrópolis: Vozes, 2015.

MORANA, Hilda C P; STONE, Michael H; ABDALLA-FILHO, Elias. Transtornos de personalidade, psicopatia e serial killers. Revista Brasileira de Psiquiatria, São Paulo, v. 28, supl. 2, p. 74-79, out. 2006.

NUCCI, Guilherme de Souza. Código de processo penal comentado. 10 ed. São Paulo: Revista dos Tribunais, 2011.

PEASE, Allan; PEASE, Bárbara. Desvendando os segredos da linguagem corporal. Rio de Janeiro: Sextante, 2005.

ROBERTO, Marcos; LUIGI, Thiago. Curso de Micro expressões Faciais: apostila técnica. São Paulo: IMELCO, 2017.

RUSSELL, James A.; FERNÁNDEZ-DOLS, José Miguel. What does a facial expression mean? In: RUSSELL, James A.; FERNÁNDEZ-DOLS, José Miguel (ed.). The

psychology of facial expression. New York: Cambridge University Press, 1997. p. 3-30. 
SCHECHTER, Harold; EVERITT, David. A enciclopédia dos serial killers: a-z. Lisboa: Guerra e Paz, 2010.

SILVA, Ana Beatriz B. Mentes perigosas: o psicopata mora ao lado. Rio de Janeiro: Objetiva, 2008.

SILVA, De Plácido e. Vocabulário Jurídico. Atualizado por Nagib Slaibi Filho e Priscila Pereira Vasques Gomes. 29. ed. Rio de Janeiro: Forense, 2012.

SILVA, Jean Luca Lunardi Laureano da et al. Possíveis contribuições dos estudos de expressões faciais para a clínica analítico-comportamental. Revista Brasileira de Terapia Comportamental e Cognitiva, Curitiba, v. 19, n. 4, p. 74-87, 2018.

SILVA, Josinete Aparecida da; SILVA, Maria Júlia Paes da. Expressões faciais e emoções humanas levantamento bibliográfico. Revista Brasileira de

Enfermagem, Brasília, DF, v. 48, n. 2, p. 1 80-1 87, abr./jun. 1995.

SOUSA, Cristina de. Emoções e expressão facial: novos desafios. Psicologia, Lisboa, v. 24, n. 2, p. 17-41, 2010.

TOURINHO FILHO, Fernando da Costa. Código de processo penal comentado. 4 ed. São Paulo: Saraiva, 1999.

VASCONCELLOS, Silvio José Lemos et al. Psicopatia e reconhecimento de expressões faciais de emoções: uma revisão sistemática. Revista Psicologia: Teoria e Pesquisa, Brasília, DF, v. 30, n. 2, p. 125-134, abr/jun 2014.

WALLACE, Alfred Russel. [Review of] The expression of the emotions in man and other animals by Charles Darwin. Quarterly Journal of Science, Londres, v. 3, n. 37, p. 113-118, 1873. Disponível em: http://darwin-online.org.uk/reviews.html. Acesso em: 31 maio 2018.

WHALEN, Paul J. et al. Neuroscience and facial expressions of emotion: the role of amygdala-prefrontal interactions. Emotion Review, [S.I.], v. 5, n. 1, p. 78-83, 2013. 